\title{
Reconstructing Holocene landscape and environmental changes at Lago Rogaguado, Bolivian Amazon
}

\author{
Alena Giesche $\cdot$ Umberto Lombardo $\cdot$ Walter Finsinger $\cdot$ Heinz Veit
}

Received: 3 October 2019/Accepted: 19 October 2020/Published online: 30 November 2020

(C) The Author(s) 2020

\begin{abstract}
We performed geochemical analyses of two lake sediment cores (1.25 and $1.5 \mathrm{~m}$ long) from Lago Rogaguado, which is a large $\left(315 \mathrm{~km}^{2}\right)$ and shallow lake in the Llanos de Moxos, Bolivian Amazon, to investigate Holocene environmental changes based on a multi-proxy dataset (XRF, density, grain size, $\mathrm{C}: \mathrm{N}$, and macrocharcoal). One of the two cores provides a history of environmental changes in the Llanos de Moxos from 8100 cal BP until present, which supplements previously published pollen and microscopic charcoal records. Our analyses indicate lake expansion at $5800 \mathrm{cal} \mathrm{BP}$, which may relate to
\end{abstract}

Electronic supplementary material The online version of this article (https://doi.org/10.1007/s10933-020-00164-8) contains supplementary material, which is available to authorized users.

The datasets used in the publication are available online: https://doi.org/10.1594/PANGAEA.924034.

\footnotetext{
A. Giesche $(\square)$

Godwin Laboratory for Palaeoclimate Research, Earth

Sciences, University of Cambridge, Downing Street,

Cambridge CB2 3EQ, UK

e-mail: alena.giesche@gmail.com

U. Lombardo $\cdot$ H. Veit

Institute of Geography, University of Bern, Bern,

Switzerland

W. Finsinger

Palaeoecology, ISEM (UMR 5554, CNRS/UM/IRD/

EPHE), Montpellier, France
}

tectonic activity. This was followed by further increasing lake levels, peaking at approximately 1050-400 cal BP, which supports increasingly wetter conditions in the Llanos de Moxos after the midHolocene. A fourfold increase in macroscopic charcoal accumulation rate and a more than fivefold increase in sedimentation rates supports anthropogenic fire activity at around $1450 \mathrm{cal} \mathrm{BP}(500 \mathrm{CE})$, suggesting that pre-Columbian populations used fire to actively manage the landscape during a period of maximum lake levels around Lago Rogaguado. From 400-100 cal BP, higher $\mathrm{C}: \mathrm{N}$, larger grain sizes and peaks in macroscopic charcoal accumulation rates suggest increased watershed erosion associated with increased biomass burning, possibly related to intensified land use.

Keywords Bolivian amazon - Llanos de moxos · Lake level · Climate $\cdot$ Land use change $\cdot$ Shallow lake

\section{Introduction}

Palaeoenvironmental reconstructions can reveal important information about past interactions between climate, the environment, and humans (Messerli et al. 2000). Besides contributing to the growing collection of palaeoenvironmental reconstructions from the Southern Hemisphere (de Souza et al. 2019), such studies are highly relevant to the ongoing debate concerning the extent and impact of human occupation 
in Amazonia (Bush and Silman 2007). Scholars debate the start of occupation as well as the extent of land use impact and deforestation through time in Amazonia. Half a century ago, Denevan (1966) claimed that far greater populations had existed here for much longer than had been previously assumed, and this idea has continued to influence our understanding of the Amazon (Denevan 1992). Instead of an untouched, unchanged landscape, it is now widely accepted that Amazonia has experienced not only climate change and natural ecosystem shifts, but also the significant impact of pre-Columbian people throughout the Holocene (Neves 2008; Schaan 2008; Arroyo-Kalin et al. 2009; Pärssinen et al. 2009; Lombardo and Prümers 2010; Whitney et al. 2013). The debate has now shifted to precisely how densely populated Amazonia may have been and where these populations were centered (Koch et al. 2019), with some researchers pointing to domesticated landscapes (Levis et al. 2017) that would have supported a preColumbian population of several millions (Erickson 2008; Clement and Junqueira 2010; Denevan 2012; Clement et al. 2015), whereas others found little evidence of large, widespread populations in the palaeoecological records (McMichael et al. 2012).

One area in Amazonia that has received attention for its relevance to the study of human-climatelandscape interactions is the Llanos de Moxos in the Bolivian Amazon (11-16 $\left.{ }^{\circ} \mathrm{S}, 63-69^{\circ} \mathrm{W}\right)$ (Fig. 1a). Interesting features of this area include the presence of thousands of earthworks (Denevan 1964), as well as evidence that Holocene climate variability impacted human settlement, migration (Lombardo et al. 2013a, 2018) and subsistence practices (Erickson 2000; Lombardo et al. 2011; Rodrigues et al. 2015).

A few palaeoenvironmental reconstructions are available for the Llanos de Moxos (Mayle et al. 2000; Urrego et al. 2013; Whitney et al. 2014; Carson et al. 2015; Brugger et al., 2016) (Fig. 1a). Brugger et al. (2016) examined the palynological record of Lago Rogaguado in the Llanos de Moxos from one of the same sediment cores used in this study. Their record indicates expanding gallery forests since $5800 \mathrm{cal} \mathrm{BP}$ that reached their maximum extent 2000 cal BP. Based on the occurrence of Zea mays and Cerealiatype pollen, the study also shows that local agricultural activity has been present since at least $6500 \mathrm{cal} \mathrm{BP}$, which is much older than previously assumed for the Bolivian Amazon. This result is consistent with
Lombardo et al. (2020), who show that cultivation began ca. 10,300 cal BP in the Llanos de Moxos, and maize was adopted around $6750 \mathrm{cal}$ BP. Finally, Brugger et al. (2016) show that the local population and crop cultivation around Lago Rogaguado did not collapse after the arrival of Europeans $500 \mathrm{cal} \mathrm{BP}$. The observation of continued occupation around Lago Rogaguado is similar to the record from El Cerro that shows a protracted decline (Whitney et al. 2014), but unlike the record of Laguna Granja (Carson et al. 2014).

Climate reconstructions from the Altiplano provide a basis for interpreting environmental changes in the lowlands, because precipitation on the Altiplano is, to some extent, recycled moisture from the Amazon (Garreaud et al. 2003). Additionally, speleothems from the Umajalanta-Chiflonkhakha cave system in the eastern Bolivian Andes (Apaéstegui et al. 2018) provide important high-resolution records of regional climate variability for the last 1400 years.

Lacustrine sediments represent one of the few suitable local palaeoenvironmental archives available in the Llanos de Moxos. Lago Rogaguado is one of many lakes in this area with complex physical characteristics (shallow, large, turbid), as well as evidence of extensive human land modification (raised fields). In this study, we investigate geochemical records to further constrain the palaeoenvironmental reconstruction of Lago Rogaguado over the past ca. 12,000 years, and discuss the palaeoenvironmental record in the context of vegetation changes deduced from its pollen record (Brugger et al. 2016). Furthermore, our study attempts to track local fire activity based on macroscopic charcoal and changes in sediment composition. Conclusions about past environmental changes are based on a multi-proxy dataset including X-ray fluorescence (XRF), grain size, density, biogenic silica, carbon:nitrogen $(\mathrm{C}: \mathrm{N})$, and macroscopic charcoal.

Study area

Lago Rogaguado is located in the Llanos de Moxos in southwestern Amazonia, Bolivia (Fig. 1a). This area falls into the upper Madeira River basin, and includes three major rivers: Beni, Mamoré, and Guaporé (also called Iténez). The Llanos de Moxos consists of wetlands spanning 100,000-155,000 km² (Hanagarth, 1993), and strong seasonality shapes the savannah 


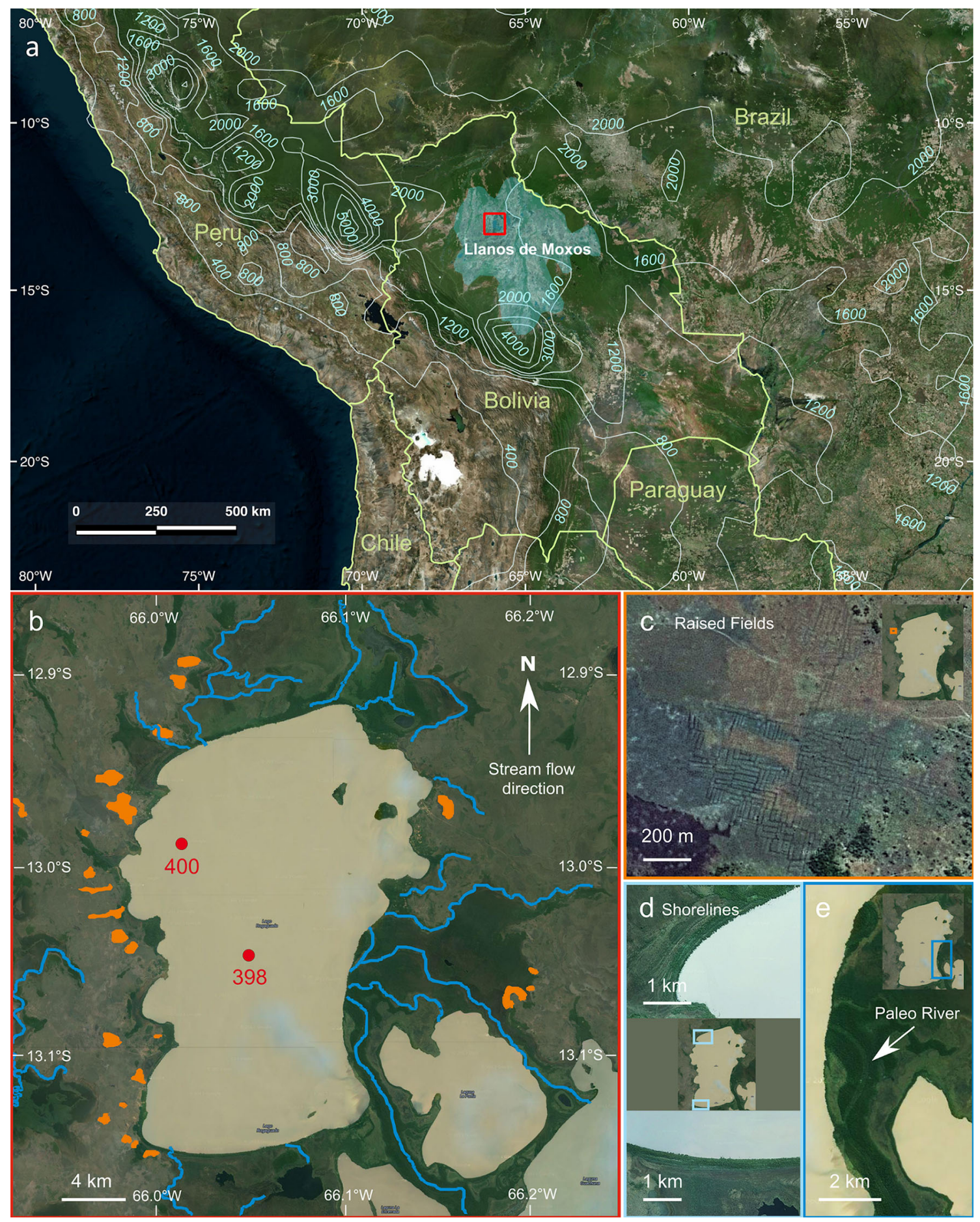

Fig. 1 a. Study location showing Lago Rogaguado's position (red square) in the Llanos de Moxos wetlands (blue shading, outline based on Walker 2011) shown with annual precipitation contours $(\mathrm{mm})$ from the $0.25^{\circ}$ GPCC v2018 dataset from 1951-2000 rain gauge data (Meyer-Christoffer et al. 2018), b. Google Earth imagery of Lago Rogaguado, showing identified palaeoriver channels (blue), pre-Columbian raised fields (orange), and the locations of both lake sediment cores analyzed in this study (LR-400 and LR-398), c. Close-ups of the raised fields, d. Northern and southern palaeoshorelines, e. Palaeoriver channel entering the lake. (Color figure online) 
landscape with forest growing on areas elevated above the seasonally flooded areas, mostly fluvial deposits (Mayle et al. 2007). Precipitation and local hydrology are the primary ecosystem drivers in the seasonally flooded Llanos de Moxos: river avulsions depend partly on upland precipitation, and lowland seasonal flooding and droughts drive the expansion of savannah, dry forest, or rain forest (Mayle et al. 2007; Lombardo 2016). During the rainy season (DecemberMay), direct precipitation as well as fluvial run-off from the Bolivian Andes inundates up to $92,100 \mathrm{~km}^{2}$ (Melack and Hess 2011). Though seemingly inhospitable to settlement, the area hosts thousands of earthworks created by pre-Columbian people, and its occupation by humans is dated to be at least 10,000 years old (Lombardo et al. 2013a, 2020; Capriles et al. 2019). Many of the prominent landscape modifications by pre-Columbian inhabitants, such as raised fields and canals, may have been made in order to adapt to this intensely fluctuating hydrological environment (Erickson 2000; Lombardo et al. 2011, 2013a; Rodrigues et al. 2015, 2016; de Souza 2019).

The Llanos de Moxos sits between the central Andes Mountains to the west and the Brazilian Shield to the east. The Nazca Ridge subduction below the Pacific side of the Andes has been ongoing since 11.2 ma (million years BP), and since 4 ma the buoyancy of this ridge caused the uplift of the Fitzcarrald Arch-an elevated boundary at $600 \mathrm{~m}$ asl running from southern Peru to Brazil (Hampel 2002; Espurt et al. 2007). The area that sits southward of this elevated bulge includes the Llanos de Moxos (mean elevation of only $150 \mathrm{~m}$ asl). From the perspective of the Andes Mountains to the west, the Llanos de Moxos is located in the foredeep of the central Andes Mountain chain, with thick Cenozoic-aged fluvial deposits that have accumulated over the deeper-lying crystalline Brazilian Shield (Plafker 1964). Relatively recent neotectonic shifts may have influenced the topography of the Fitzcarrald Arch, further affecting areas in the northern Llanos de Moxos (Lombardo 2014). Such tectonic movements triggered river avulsions, fluvial deposits, sediment erosion, and formation of numerous oxbow and ria lakes throughout the lowlands (Dumont and Fournier 1994; Lombardo 2014). Specifically, the area around Lago Rogaguado is located south of a proposed fault line (Linea Bala-Rogaguado). Hanagarth (1993) and later Dumont (1996) proposed that tectonic uplift related to this fault dammed a valley and formed several lakes, among them Lago Rogaguado.

Presently, Lago Rogaguado is a turbid freshwater basin, located in a transition zone between Cerradolike dry savannah and tropical rainforest. Climatically, the lake is influenced by the strongly fluctuating hydrological environment of the Llanos de Moxos, with a combination of pronounced dry and rainy seasons. The area immediately surrounding the lake is distinct for the presence of hundreds of elongated raised fields, created at some point in the past by preColumbian populations (Tyuleneva 2010; Rodrigues 2016).

Lago Rogaguado is flanked by the Yata River and the Beni River to the northwest and the Mamoré River to the southeast. Although there are no permanent fluvial inflows or outflows, the lake receives overflow from swamps located to the southwest during the rainy season. Additional groundwater inputs to the lake could not be ruled out. In the past, the Beni River may have flowed through the area now occupied by the lake (Lombardo 2014), as is also suggested by the presence of a distinct palaeochannel entering the southeastern shore of the lake (Fig. 1e). The soils on the eastern and western sides of the lake are lateritic, and therefore nutrient-poor, low-pH, and high in iron and aluminum (Navarro-Sánchez 2011; Lombardo et al. 2013b). Lateritic soils, such as those flanking Lago Rogaguado, typically have a high density of $2.5-3.6 \mathrm{~g} \mathrm{~cm}^{-3}$, are quite acidic, and contain mainly secondary forms of iron (40-90\%), secondary aluminum (5-50\%), and some kaolinite and quartz (though silica is mostly weathered out) (Young 1980). Rivers stemming from the Andes, such as the Beni River in the Madeira Basin, are an important source of Si for leached tropical soils in the Amazonian lowlands, as dissolved $\mathrm{Si}$ is up to $50 \%$ of the load in solution and more than half of the rivers' total sediment load (ranging from 20-18,000 $\mathrm{t} \mathrm{km}^{-2} \mathrm{yr}^{-1}$ ) is deposited in the Llanos floodplains each year mainly between January and March (Guyot 1992). As a result, tropical soils with high aluminum (Al) and iron (Fe) can be easily distinguished from fluvial sediments eroded from the Andes that are enriched in silica (Si) (Stallard and Edmond 1983; Guyot 1992).

Overall, the vegetation around Lago Rogaguado is a mixture of woody savannahs and drought-tolerant forests, as well as swamps to the north and south of the lake. Two forested islands (around $1 \mathrm{~km}^{2}$ and $0.5 \mathrm{~km}^{2}$ ) 
are located in the northeastern part of the lake. Some areas around the lake are actively farmed today (manioc and various fruit trees were observed), and large Mauritia flexuosa palm trees surround the shorelines, partly submerged in shallow water. A full vegetation description of the surrounding area is given in Brugger et al. (2016).

\section{Materials and methods}

Fieldwork, coring, and correlating cores

Sediment cores were taken from the large $\left(315 \mathrm{~km}^{2}\right)$ flat-bottomed, shallow (2-3 $\mathrm{m}$ average depth) Lago Rogaguado $\left(13^{\circ} 2^{\prime} \mathrm{S} ; 65^{\circ} 56^{\prime} \mathrm{W}\right)$ in two coring locations: LR-400 and LR-398 (Fig. 1b). While LR-398 is in the center of the lake $4 \mathrm{~km}$ from the nearest shoreline at $2.9 \mathrm{~m}$ water depth, site LR-400 is located only $2 \mathrm{~km}$ from the western shoreline at $2.5 \mathrm{~m}$ water depth (Fig. 1b). In 2012, short sediment cores were retrieved from each coring location (LR-400-12 and LR-398-12 of lengths $82 \mathrm{~cm}$ and $73 \mathrm{~cm}$, respectively) using a gravity-coring device (UWITEC). These locations were re-cored in 2013 with a Livingstone piston corer from a floating boat platform (Livingstone 1955; Cushing and Wright 1965) in order to obtain longer sediment records. The lengths of the 2013 cores were $125 \mathrm{~cm}$ and $150 \mathrm{~cm}$ for LR-400-13 and LR-39813 , respectively, and were limited only due to the increasing density of the sediment and our reliance on manual power to pull out the cores. GPS-based relocation of the coring sites between the two fieldwork campaigns in 2012 and 2013 may differ by up to $100 \mathrm{~m}$. The LR-398-13, LR-400-12, and LR-400-13 cores were subjected to a series of laboratory procedures upon arriving in Bern, Switzerland. The scanning procedures included XRF scanning with an ITRAX scanner and density measurements with a Geotek Multi-Sensor Core Logger (MSCL). Subsamples from the other core half were used for ${ }^{14} \mathrm{C}$ dating, grain size determination, carbon:nitrogen $(\mathrm{C}: \mathrm{N})$ ratio, and macroscopic charcoal. Short core LR-400-12 was analyzed for pollen, microscopic and macroscopic charcoal by Brugger et al. (2016) (named core C1A in their publication).

The short LR-400-12 and long LR-400-13 cores were correlated based on visual comparison as well as XRF measurements (ESM Fig. S1). The LR-400-12 core and the top of the LR-400-13 core could be matched with no offset, so the bottom section of core LR-400-13 is accordingly treated as an extension of LR-400-12. Hereafter, the composite core consisting of LR-400-12 and LR-400-13 is referred to as LR-400, whereas LR-398 refers to core LR-398-13.

\section{Chronologies}

The chronology of core LR-400 is based on 7 radiocarbon dates (Brugger et al. 2016). Three new radiocarbon dates measured on bulk sediments were not used to update the depth-age model because such radiocarbon dates often provide older ages than the age of sediment deposition (Björck and Wohlfarth 2001). The depth-age model (Brugger et al. 2016) was made for the upper 8000 years of the record at site LR400 using CLAM v2.2 (Blaauw 2010) (ESM Fig. S2). This model was constrained by ${ }^{14} \mathrm{C}$ dates on terrestrial plant macrofossils and passes through the $2 \sigma$ error range of the calibrated ages in order to account for sample depth and age uncertainties (Birks and Heegaard 2003; Heegaard et al. 2005). For core LR-398, only two ${ }^{14} \mathrm{C}$ dates are available, which nonetheless enable comparison of this core to the age model of LR400. The SHCAL13.14 dataset was used to calibrate all of the radiocarbon ages to calendar years before present (cal BP) (Hogg et al. 2013), using Calib 7.0 (Stuiver and Reimer 1993).

XRF scanning

We determined the elemental composition of the splitcore surface with the ITRAX scanner (Croudace et al. 2006). The LR-400-13 and LR-398-13 cores were scanned with a Mo-tube at 2-mm resolution for $10 \mathrm{~s}$ per measurement, with a $35 \mathrm{kV}$ and $35 \mathrm{~mA}$ setting. Elemental intensities measured by the XRF ITRAX are recorded in counts per second (cps); hence, they are semi-quantitative measures. A total of 51 elements were scanned, and we focus on seven of these elements (Al, Fe, K, Rb, Si, Ti, and $\mathrm{Zr}$ ) because their ratios are suitable as local environmental indicators (Davies et al. 2015).

Density and water content

Gamma density measurements $\left(\mathrm{g} \mathrm{cm}^{-3}\right)$ were derived from the Geotek MSCL, using the Gamma Ray 
Attenuation Porosity Evaluator. All unopened cores were scanned at $0.5-\mathrm{cm}$ intervals, and measurements were calibrated using a standard water-filled tube made of the same material and diameter as the sediment tubes. Water content by weight loss was analyzed at $1-\mathrm{cm}$ intervals.

\section{Grain size}

Grain size samples for the LR-400-12 and LR-400-13 cores as well as depths 122-66 cm of the LR-398-13 core were prepared at $1-\mathrm{cm}$ resolution following Sun et al. (2002). $10 \mathrm{ml}$ of $30 \% \mathrm{H}_{2} \mathrm{O}_{2}$ was added to approximately $1 \mathrm{~g}$ of sediment to remove organic matter, more $\mathrm{H}_{2} \mathrm{O}_{2}$ was added as needed, and the samples were heated in a warm water bath of $60{ }^{\circ} \mathrm{C}$ for six hours. The samples were then rinsed with distilled water twice, centrifuged, given $20 \mathrm{ml}$ of a $4.7: 1$ dispersant mixture of sodium hexametaphosphate $\left(\mathrm{NaPO}_{3}\right)_{6}$ and sodium carbonate $\left(\mathrm{Na}_{2} \mathrm{CO}_{3}\right)$, and filled with water up to $40 \mathrm{ml}$. The prepared samples were measured using the Malvern Mastersizer 2000, which ran an automated standard operating procedure with high-stirrer settings. The samples received uniform treatment: the tubes were shaken by hand for $10 \mathrm{~s}$, uncapped, tipped at an angle, and approximately $5 \mathrm{ml}$ of each $40 \mathrm{ml}$ sample was pipetted into the sample chamber of the Mastersizer instrument.

\section{Biogenic silica (BSi)}

The BSi content was investigated in 36 samples from core LR-400 (every $4 \mathrm{~cm}$ throughout the core, and every $\mathrm{cm}$ for the bottom $8 \mathrm{~cm}$ ). The samples were prepared as in Carter and Colman (1994): $30 \% \mathrm{H}_{2} \mathrm{O}_{2}$ was added to $100 \mathrm{mg}$ of dry sample to remove organic material, followed by washing and centrifuging, and freeze-drying. In a plastic PP-tube, $10 \mathrm{ml}$ of $1 \mathrm{M}$ $\mathrm{NaOH}$ solution was added for $3 \mathrm{~h}$ with heat and agitation to leach the mineral and biogenic silica from the sample, followed by centrifuging and extraction of the supernatant liquid. The silica reaction in the supernatant was stopped by adding $70 \mu \mathrm{l}$ of $65 \%$ $\mathrm{HNO}_{3}$ and $12 \mathrm{ml}$ of water to $700 \mu \mathrm{l}$ of the supernatant. The supernatant $\mathrm{Si}$ and $\mathrm{Al}$ was measured by Inductively-Coupled-Plasma Optical Emission Spectrometry (ICP-OES) at the Paul Scherrer Institute.
Carbon:nitrogen ratios $(\mathrm{C}: \mathrm{N})$

C:N ratio of the LR-400-12, LR-400-13, and LR-39813 cores was measured at a $1-\mathrm{cm}$ resolution (measurements were discontinuous for the top and bottom of core LR-398-13). Approximately $40 \mathrm{mg}$ of dried/ homogenized sample material was weighed and wrapped into tin capsules. Approximately every tenth sample was repeated in triplicate to assess the $\pm 1 \sigma$ standard deviation, which was 0.003 for TN, 0.05 for TOC, and 0.25 for C:N. The capsules were combusted by a vario EL cube CNS analyzer, and the resulting data provides the total organic carbon (TOC), total nitrogen (TN), as well as $\mathrm{C}: \mathrm{N}$ of the measured samples.

To assess only the organic and not inorganic carbon content of the sediments, we used a two-step loss-onignition (LOI) procedure (Dean 1974; Heiri et al. 2001). After testing four samples for a reaction with $10 \% \mathrm{HCl}$, as well as checking LOI at $1100{ }^{\circ} \mathrm{C}$ for four additional samples, the Lago Rogaguado sediments were deemed to contain negligible amounts of inorganic carbon (ESM Fig. S3), and thus the LOI analysis was omitted for all other samples.

\section{Macroscopic charcoal}

We use macroscopic charcoal to track local fire history because the large size of macroscopic charcoal particles restricts their transport, unlike microscopic charcoal particles (Tinner et al. 1998; Whitlock and Larsen 2001). For macroscopic charcoal, 1-cm thick samples were taken contiguously from core LR-40012. The samples $\left(2 \mathrm{~cm}^{3}\right.$ in volume) were deflocculated, sieved to $>160-\mu \mathrm{m}$ mesh size, identified, counted, and measured under a stereomicroscope following Finsinger et al. (2014). The data were first interpolated at a 150-year time interval and then smoothed with a lowess filter (Cleveland 1979) using an 800-year window width that maximizes the signalto-noise index, as implemented in the CharAnalysis software (Higuera et al. 2009). 


\section{Results}

Chronology of the sediment cores

The two lowermost radiocarbon dates of core LR-400 reached an age of ca. 11,300 cal BP (ESM Table S1). For the rest of the core we used the depth-age model for the sediments in the top $80 \mathrm{~cm}$ of site LR-400 as previously published by Brugger et al. (2016) (ESM Fig. S2).

The depth-age model of core LR-400-12 revealed a shift in sedimentation rate after $36 \mathrm{~cm}$ depth $(1050 \mathrm{cal}$ BP). The average sedimentation rate for the top $36 \mathrm{~cm}$ was $0.04 \mathrm{~cm} \mathrm{yr}^{-1}$, while the average rate for $80-37 \mathrm{~cm}$ was far lower $\left(0.006 \mathrm{~cm} \mathrm{yr}^{-1}\right)$. The inferred sediment deposition time was $160 \mathrm{yrs} \mathrm{cm}^{-1}$ for the bottom part of the core, and $30 \mathrm{yrs} \mathrm{cm}^{-1}$ for the top part of the core- a more than fivefold increase in sediment accumulation rate from the bottom to the top of the core. The variations in sediment accumulation matched density, with denser sediments at the bottom (Fig. 2).

Geochemistry of the sediment cores

The coring sites LR-400 and LR-398 are separated by a distance of $8 \mathrm{~km}$ and receive different amounts of sediment based on their distance from the shoreline (LR-398 is twice as far from the shoreline as LR-400). Nevertheless, based on XRF data, ${ }^{14} \mathrm{C}$ dates, and visual stratigraphic changes, the records of the two cores could be correlated with some confidence (ESM Fig. S4). The lacustrine records began to match at $68 \mathrm{~cm}$ (LR-400) and $59 \mathrm{~cm}$ (LR-398), as confirmed by the radiocarbon dates as well as by elemental ratios.

\section{Early Holocene}

The age of the material in the lowest $43 \mathrm{~cm}$ of LR-400 (125-82 cm depth) was uniform, and there were no laminations: two bulk sediment dates from depths $118 \mathrm{~cm}$ and $85 \mathrm{~cm}$ yielded ages of 11,279 \pm 70 and $11,278 \pm 78$ cal BP, respectively. Grain size at the very bottom was predominantly clay, followed by mostly fine silt and clay above $118 \mathrm{~cm}$ (ESM Fig. S5a). We observe an increase in $\mathrm{Zr}: \mathrm{Rb}$ and Si:K (ESM Fig. S4) from 125-82 cm and a lack of biogenic silica in core LR-400 (ESM Fig. S6). The highest Al, $\mathrm{Fe}$, and $\mathrm{K}$ counts were also recorded in the bottom of core LR-400, along with total organic carbon (TOC) values of $<1 \%$ and highest density (Fig. 3a). A Principle Component Analysis (PCA) of core LR-400 helps to further visualize the variability explained by the XRF data, mean grain size, and TOC (ESM Fig. S7).

The bottom of core LR-398 $(150-118 \mathrm{~cm})$ was characterized by high and decreasing $\mathrm{Al}, \mathrm{Fe}$, and $\mathrm{K}$ counts, while $\mathrm{Ti}, \mathrm{Zr}$, and $\mathrm{Si}$ counts reached a relatively high plateau from 118-70 cm (Fig. 3b). In addition, the bottom of the core is rich in bright orange-colored oxides. An organic-rich layer followed the oxidized sediments until $70 \mathrm{~cm}$, and the grain size data showed high variance in the entire Section 150-70 cm (ESM Fig. S5b).

\section{Mid-late Holocene}

We found a prominent change in $\mathrm{C}: \mathrm{N}$ ratio (Fig. 3a) of core LR-400 at 81-82 cm depth (around $8100 \mathrm{cal} \mathrm{BP).}$ The $\mathrm{C}: \mathrm{N}$ ratio peaked to a value four times its previous levels - from around 4 to 16 . This shift was matched by the peak in TOC ( $>3 \%)$ at this depth. At the same time, XRF elemental counts showed a drop in $\mathrm{Al}, \mathrm{Si}$, and Ti (Fig. 3a). The Si:K ratio started to decrease, whereas the $\mathrm{Zr}: \mathrm{Rb}$ ratio maintained its highest values until $66 \mathrm{~cm}$ (5650 cal BP). This change in sediment composition (high TOC, lower Si:K) occurred despite continued input of coarser particles and higher water transport energy (high $\mathrm{Zr}: \mathrm{Rb}$ ). C:N in core LR-400 dropped sharply from 14 to 10 at $68 \mathrm{~cm}$ depth (5700 cal BP), and the $\mathrm{Zr}: \mathrm{Rb}$ ratio dropped immediately afterwards.

Core LR-398 changed dramatically with the appearance of the distinct clay layer between 70 and $59 \mathrm{~cm}$ that was not found in core LR-400. The age of this shift $(5792 \pm 149$ cal BP) was constrained by a ${ }^{14} \mathrm{C}$-dated wood fragment just above the clay layer in core LR-398. After this point, cores LR-400 and LR398 represent similar lacustrine sediment deposition. The clay layer was characterized by its light gray color and very high $\mathrm{K}, \mathrm{Rb}$, and $\mathrm{Sr}$ counts juxtaposed against low $\mathrm{Si}, \mathrm{Ti}$, and $\mathrm{Zr}$ (all elements besides calcium showed a very distinct change in this layer) (Fig. 3b). The shift at $70 \mathrm{~cm}$ was also shown clearly by the sharp drop and decreased variance of $\mathrm{Rb}: \mathrm{K}$, which persisted until the top of the core.

At $\sim 63 \mathrm{~cm}$ depth (5350 cal BP) in core LR-400, the grain size record reached its peak in sand and 


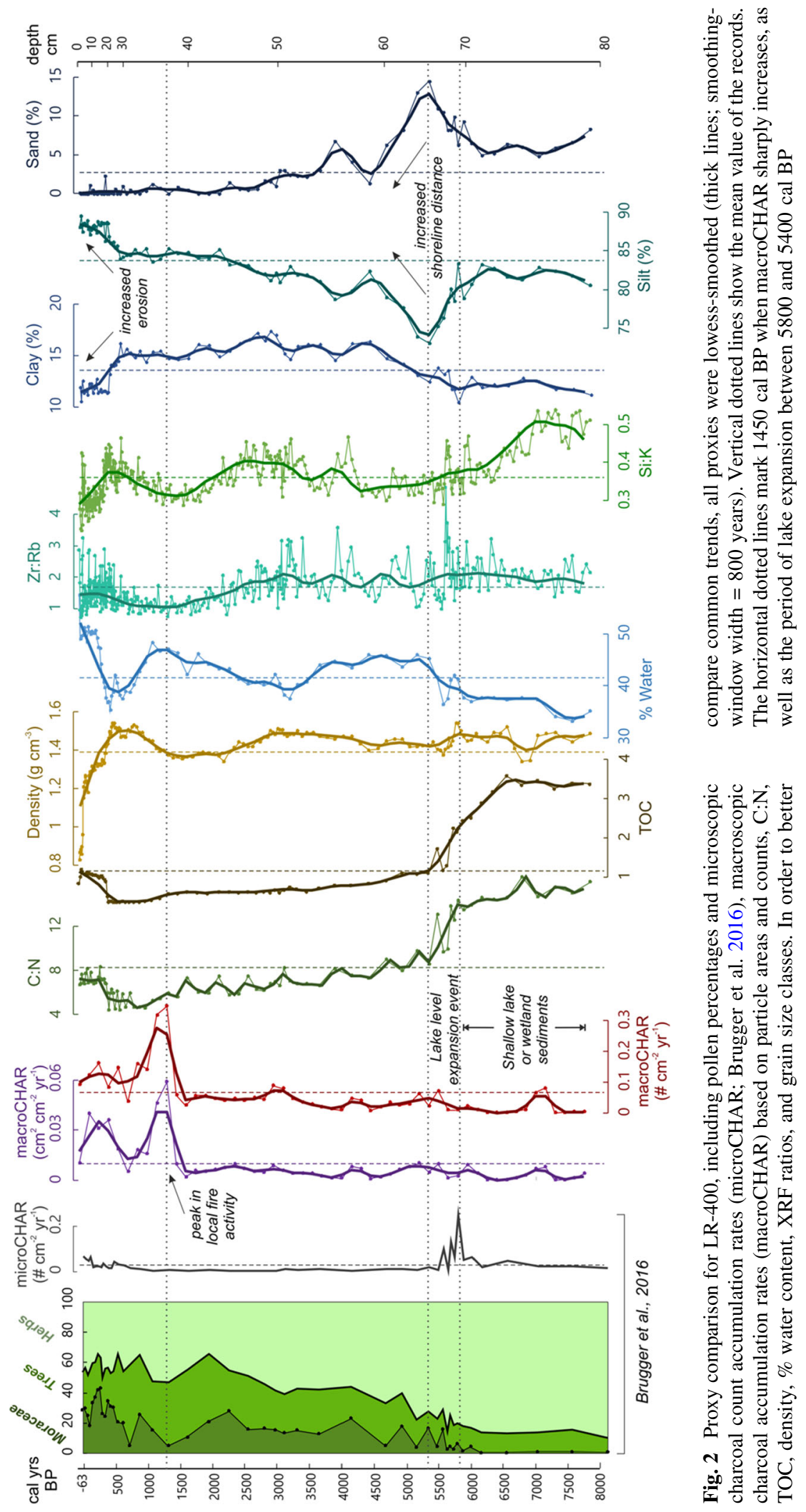



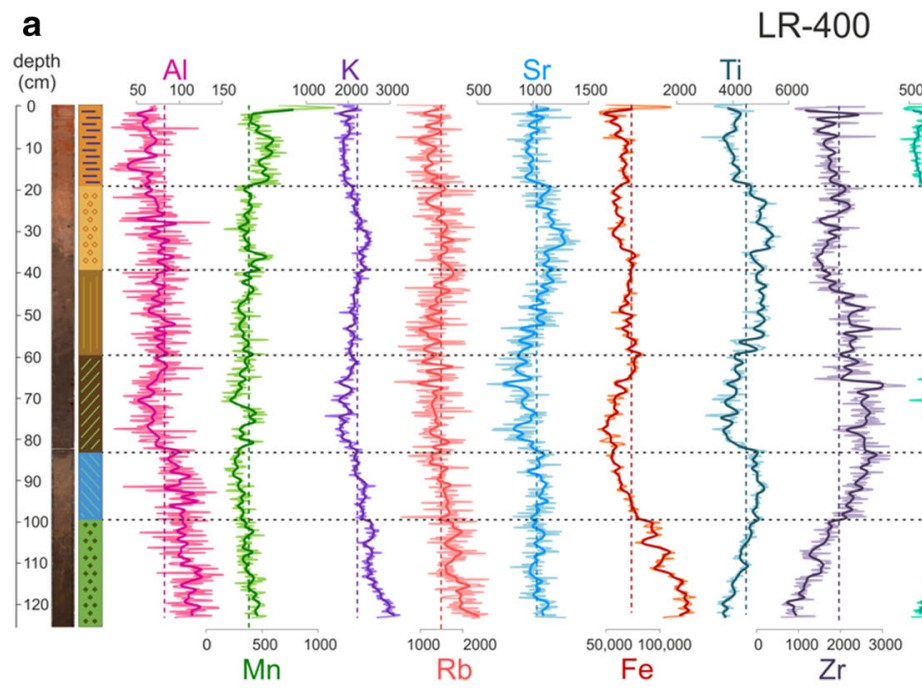

LR-400

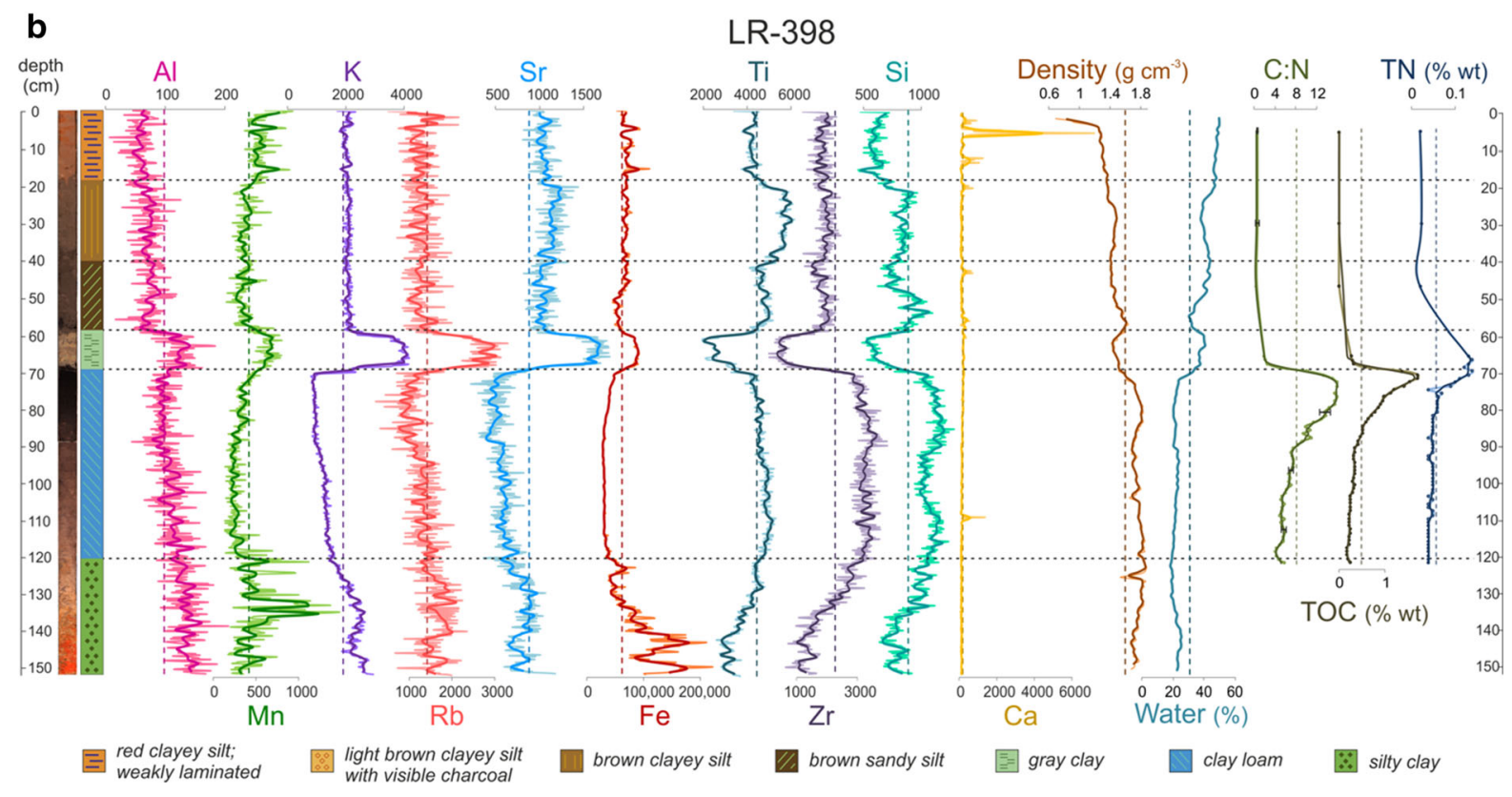

Fig. 3 XRF scans for ten elements (Al, Si, K, Ca, Ti, Mn, Fe, $\mathrm{Rb}, \mathrm{Sr}, \mathrm{Zr}$ ), density, \% water content, $\mathrm{C}: \mathrm{N}$ ratio, Total Organic Carbon (TOC), and Total Nitrogen (TN) as percentage of dry weight (\% wt) presented for a. site LR-400 and b. site LR-398. Horizontal dotted lines show sedimentological changes in the

thereafter transitioned to fine silt. XRF data showed relatively gradual changes between 68 and $36 \mathrm{~cm}$ (5700-1050 cal BP), accompanied by decreasing C:N. From $36-22 \mathrm{~cm}(1050-400 \mathrm{cal} \mathrm{BP})$, there was a period of minimum $\mathrm{C}: \mathrm{N}$, lowest TOC, higher Si:K and increasing $\mathrm{Zr}: \mathrm{Rb}$, increased density and lower water content, shift to higher sedimentation rate, as cores, and vertical dashed lines represent the mean value of the records. Note that $\mathrm{C}: \mathrm{N}$ measurements were discontinuous for the top and bottom of core LR-398, and error bars representing $\pm 2 \sigma$ are shown for the triplicate samples in both $\mathrm{C}$ :N plots

well as higher $\mathrm{Ti}, \mathrm{Sr}$, and lower $\mathrm{Fe}$. A transition to slightly higher C:N, TOC, and silt-sized fraction starts at $22 \mathrm{~cm}(400 \mathrm{cal} \mathrm{BP})$ and a general shift in all XRF series was seen at $20 \mathrm{~cm}$ (350 cal BP). The most recent sediments (top $20 \mathrm{~cm}$ ) were characterized by relatively higher $\mathrm{C}: \mathrm{N}$ values, slightly coarser grain 
size and increased $\mathrm{Zr}: \mathrm{Rb}$, decreased $\mathrm{Si}: \mathrm{K}$, and some spikes in the Ca record.

Core LR-398 shows a sequence of geochemical transitions similar to LR-400 after $5800 \mathrm{cal}$ BP, although this location features a lower sedimentation rate. The two sediment cores were separated by a distance of several kilometers in Lago Rogaguado (Fig. 1b).

Macroscopic charcoal of site LR-400

Our 1-cm resolution macroscopic charcoal record doubled the resolution of the previously published record (Brugger et al. 2016), and excellent agreement between both records validates the consistency of this proxy. Both count-based and area-based macroscopic charcoal accumulation rates were highly correlated in core LR-400 (Fig. 2). Macroscopic charcoal accumulation rates (macroCHAR) remained almost entirely below average for depths $80-40 \mathrm{~cm}(8100-1600 \mathrm{cal}$ $\mathrm{BP}$ ), and then jumped to the highest values of 0.4 pieces $\mathrm{cm}^{-2}$ year $^{-1}$ at $39 \mathrm{~cm}$ (1450 cal BP). After the maximum at $1450 \mathrm{cal} \mathrm{BP}$, macroCHAR values gradually but variably decreased. A smaller maximum was centered between 400 and $100 \mathrm{cal} \mathrm{BP}$. In the top sediments, macroCHAR values remained consistently higher than what was observed in the bottom half of the core.

\section{Discussion}

A comparison of the grain size and geochemical records shows differences between the cores prior to 5800 cal BP (ESM Fig. S4 and S5). We interpret these to be a result of different depositional environments and explore several mechanisms (tectonics, climate, river runoff) that could have caused the lake level and environmental changes suggested by our proxies. We also focus on changes in several proxies over the past 1500 years because this is a key period in the land use history of the Llanos de Moxos (Walker 2004; Lombardo et al. 2013b; Prümers and Betancourt 2014; Rodrigues et al. 2015). Thus, we extend the pollen-based understanding of the past human-environment interactions at this site (Brugger et al. 2016) with information from additional geochemical proxies.
Lake basin formation and fluvial dynamics

The causes and timing of the formation of Lago Rogaguado's basin are uncertain; however, a tectonic history for the area around Lago Rogaguado has been proposed (Hanagarth 1993; Dumont 1996). Dumont (1996) concluded that the parallel positioning of lakes along a faultline, their elongated shape, and hardened clay deposits were related to subsidence and faulting. Lombardo (2014) described the fluvial and neotectonic dynamics in the region, and suggested the uplift of the Fitzcarrald Arch as a possible formation mechanism for the lake basin itself. Prior to the basin formation during the late Pleistocene or early Holocene, the Beni River (now located to the northwest of Lago Rogaguado) likely flowed through the former valley that is now Lago Rogaguado (Lombardo 2014). Indeed, the remnants of a large river channel cut by the southeastern shores of Lago Rogaguado are apparent in satellite imagery (Fig. 1e). The dense, unstratified, and $\mathrm{Si}$-enriched basal sediments from cores LR-398 and LR-400 support the hypothesis of periodic overbank flooding over tropical swamp soils. The uniform ages of the material in the lowest $43 \mathrm{~cm}$ of LR-400 (125-82 cm depth) likely reflect a bioturbated soil/swamp setting rather than a discrete deposition event, and such radiocarbon dates measured on bulk sediments (both ca. 11,300 cal BP) often provide older ages than the age of sediment deposition (Björck and Wohlfarth 2001). The increase in $\mathrm{Zr}: \mathrm{Rb}$ and $\mathrm{Si}: \mathrm{K}$ (ESM Fig. S4) from $125-82 \mathrm{~cm}$ and the lack of biogenic silica in core LR-400 (ESM Fig. S6) suggests that the silica content in Lago Rogaguado is lithogenic rather than biogenic, probably resulting from an input of coarser silica-enriched sediments. The bright orange-colored oxides at the bottom of core LR-398 indicate a hydromorphic soil, compatible with a soil forming in a backswamp. The Beni River frequently shifted course in the past, and at some point (likely before $5800 \mathrm{cal} \mathrm{BP}$ ) it crossed the Bala-Rogagua line to a channel north of Lago Rogaguado (Hanagarth 1993; Dumont 1996; Plotzki et al. 2011). Like other shallow lowland Amazonian lakes that preserve biogenic silica poorly (Bush et al. 2016), the high $\mathrm{Si}$ K of Lago Rogaguado's basal sediments in both cores represents fluvial input of Si-rich sediment sources. We found that these Si-enriched sediments in LR-398 (150-70 cm) included heavily weathered clays (high Rb:K; Brown 2011; Burnett et al. 2011), 
and the accompanying lack of stratification and higher $\mathrm{C}: \mathrm{N}$ and density (Fig. 3b) supports the hypothesis that this was a tropical swamp soil. Likewise, for LR-400 $(125-82 \mathrm{~cm})$, sediments were denser and unstratified, with higher $\mathrm{Si}$ and uniform ages that likely reflect mobile carbon in a shallow, bioturbated swamp soil (Fig. 3a).

\section{Mid-Holocene lake expansion}

Due to Lago Rogaguado's combination of large surface area and shallow depth, any significant lake level changes would have had an impact on the composition and grain size of sediments being deposited. Cores LR-398 and LR-400 show different sedimentation histories in their lower sections. A start of lake sediment accumulation in core LR-400 at around 8100 cal BP indicates that site LR-400 was located in a shallow lake or wetland. This is supported by the high amounts of the alga Botryococcus (which prefers calm, shallow water) found in core LR-400 between 80 and $69.5 \mathrm{~cm}$ depth (8100-5800 cal year $\mathrm{BP}$ ), as well as semiaquatic pollen indicating the presence of a wetland or shallow lake (Brugger et al. 2016). In contrast, a hydromorphic soil persisted until $5800 \mathrm{cal} \mathrm{BP}$ at site LR-398. This was buried by a distinctive clay layer and followed by lake sediment deposition after $5790 \pm 150 \mathrm{cal}$ BP (date from a wood macrofossil at the top of the clay layer), which marked the expansion of the lake area. Based on the evidence, the area around Lago Rogaguado was probably partially covered with small wetlands and oxbow lakes during the early-mid Holocene.

An abrupt shift in several of Lago Rogaguado's proxies occurred between 5800 and $5700 \mathrm{cal} \mathrm{BP}$, all pointing to a rapid lake expansion. Most prominently, an 11-cm clay layer was deposited at the second coring site (LR-398) located in the middle of the present-day lake. In core LR-400, a drop in the C:N ratio from 14 to 10 occurred in just one centimeter (Fig. 3a) along with an increase in sedimentation rate and a drop in the $\mathrm{Zr}: \mathrm{Rb}$ ratio (ESM Fig. S4b). Sediments are generally size-sorted with increased transport distance from the inflow (Håkanson and Jansson 2002; Last 2002), and the deposition of coarser material can be interpreted as higher transport energy from increased water inflow or closer sediment source due to lower lake levels. A drop in the $\mathrm{Zr}: \mathrm{Rb}$ ratio supports a decrease in water transport energy, again due to more distant shorelines, with $\mathrm{Zr}$ representing heavy minerals and $\mathrm{Rb}$ representing lighter clays (Kylander et al. 2011; Chawchai et al. 2013). A rapid decrease in $\mathrm{C}: \mathrm{N}$ ratio points to a decreased influx of terrestrial organic material to site LR-400, which could happen if a smaller wetland area expanded into a much larger lake. Furthermore, despite the lower resolution in core LR-398, the C:N ratio values in that core $(60-0 \mathrm{~cm})$ were substantially lower than in core LR-400, likely because coring site LR-398 was further away from the shoreline. For instance, in Lake Victoria, the C:N ratio of surface sediment samples decreased with distance from shoreline-from 16.4 at the swampy margin to only 11.6 at a distance $400 \mathrm{~m}$ offshore (Talbot and Laerdal 2000; Meyers and Teranes 2001). In a parallel case from Laguna Potrok Aike in Argentina, lake level changes were reconstructed based on $\mathrm{C}: \mathrm{N}$ ratios, which reflected increased input from shallow water macrophytes (tested to have a $\mathrm{C}: \mathrm{N}$ of 24-29) that were tied to lower lake levels and less transport distance to the coring site (Haberzettl et al. 2005). While C:N ratios may additionally reflect changes in lake internal productivity or sediment reworking of the shoreline (Lombardo and Veit 2014; Zhan et al. 2014), the alignment with grain size and XRF proxies such as $\mathrm{Zr}: \mathrm{Rb}$ lends additional support to the scenario of lake level changes at Lago Rogaguado. The two sediment cores were separated by a distance of several kilometers in Lago Rogaguado (Fig. 1b) and their distance to the shoreline differed substantially, influencing the amount of run-off from the catchment reaching each of the coring locations. Sediment reworking and depositional adjustments after the major lake expansion event may have continued for several centuries, as seen by the peak in the sand grain size fraction between 5800 and 5400 cal BP (Fig. 2).

Both neotectonic (Lombardo 2014) and climatic (Brugger et al. 2016) causes have been proposed for the expansion of Lago Rogaguado at $5800 \mathrm{cal} \mathrm{BP}$. We argue that a neotectonic origin for the expansion of Lago Rogaguado at 5800 cal BP is more likely, based on the evidence of rapid sedimentological and geochemical changes in both cores. Local geologic evidence of tectonics has been attributed to subduction of the Nazca Ridge, which could have caused uplift and dammed the valley at the northern limit of Lago Rogaguado to form a so-called ria lake (Lombardo 2014). Concurrently, climate reconstructions from the Altiplano (Baker et al. 2001; Tapia et al. 2003; Weide 
et al. 2017), Peruvian Andes (Kanner et al. 2013), and southwestern Amazonia (Mayle and Power 2008; Urrego et al., 2009; Novello et al., 2017), show that the period between $\sim 8000$ and 4500 cal BP was exceptionally dry. Notably, Lake Titicaca salinity peaks around $4500 \mathrm{cal} \mathrm{BP}$ (Tapia et al. 2003). At Laguna La Gaiba in the Brazilian Pantanal, forest decline was forced by drought in the mid-Holocene (Whitney et al. 2011) matching drier conditions inferred from leaf wax isotopes between 9000 and $6000 \mathrm{cal} \mathrm{BP}$ (Fornace et al. 2016), while carbonate content indicates continued evaporative lake conditions until $\sim 4500 \mathrm{cal} \mathrm{BP}$ (Metcalfe et al. 2014). This supports a non-climatic cause for Lago Rogaguado's rapid expansion at $5800 \mathrm{cal} \mathrm{BP}$, though it does not rule out further lake level rise due to climatic changes afterwards.

Mid-late Holocene lake level fluctuations

Trends in Amazonian moisture over the Holocene can be explained by solar insolation changes that drive the position of the Intertropical Convergence Zone (ITCZ) (Mayle et al. 2000) and strength of the South American Monsoon (SAM) (Zhou and Lau 1998). Overall, palaeoclimate studies from southwestern Amazonia show decreased moisture availability over the early-mid Holocene, in contrast to increased moisture over this time in northeastern Amazonia (Cruz et al. 2009; Cheng et al. 2013). In southwestern Amazonia, most palaeoecological studies show evidence of wetter conditions since the mid-Holocene, though with staggered onset: $5800 \mathrm{cal}$ BP (Brugger et al. 2016), 3000 cal BP (Mayle et al. 2000), $2500 \mathrm{cal}$ BP (Carson et al. 2014), and 1200 cal BP (Taylor et al. 2010). Continuous forest cover over the mid-Holocene was reconstructed in the Upper Beni, suggesting that such ecotones were relatively stable and resilient despite changes in moisture availability (Urrego et al. 2013). The discrepancy between Amazonian palaeoclimate reconstructions highlights the heterogeneity of Amazonian climate and ecosystems, as emphasized by Bush et al. (2011) and Mayle et al. (2004).

After the expansion of Lago Rogaguado at $5800 \mathrm{cal}$ $\mathrm{BP}$, the C:N ratio of LR-400 steadily decreased until reaching its minimum at $1050 \mathrm{cal} \mathrm{BP}$. The values remained below 6 until $400 \mathrm{cal}$ BP, indicating a relatively long period of elevated lake levels. Simultaneously, the sand fraction of grain size was progressively replaced by silt between 5800 and 400 cal BP
(Fig. 2). These new findings provide pollen-independent evidence for increasing moisture availability, which was hypothesized as the trigger for expanding gallery forests at Lago Rogaguado (Brugger et al. 2016). Increased moisture in the late Holocene is welldocumented in the Altiplano (Baker et al. 2001; Tapia et al. 2003; Weide et al. 2017). A diatom-based study of lake level changes in Lake Titicaca's southern basin showed an increase in freshwater planktic species at 1250 cal BP, marking conditions of lowest salinity (Weide et al. 2017). This is supported by Lake Titicaca, which reached modern high lake levels at around 1500 cal BP (Tapia et al. 2003). Similarly, a speleothem-based palaeoclimate reconstruction from the eastern Bolivian Andes showed especially wet conditions during the Medieval Climate Anomaly (MCA) 1050-850 cal BP (Apaéstegui et al., 2018). These increases in moisture occurred during the time of highest lake levels at Lago Rogaguado.

From $400-0 \mathrm{cal}$ BP, the C:N ratio increased again slightly, indicating an increase in terrestrial input and a possible decrease in lake levels. A sequence of undated palaeoshorelines at the northern and southern limits of the lake, visible from satellite images (Fig. 1d), may be remnants of former higher-thanpresent lake levels. Around $400 \mathrm{cal} \mathrm{BP}$, the $\mathrm{Zr}: \mathrm{Rb}$ ratio also increased, while the clay fraction of grain size was progressively replaced by silt. This indicates increased erosion, perhaps from a change in anthropogenic land use. Figure 4 illustrates the proposed hydrological scenario for Lago Rogaguado from 8100 cal BP until present.

Our new findings further clarify and add to the pollen-inferred environmental changes around Lago Rogaguado (Brugger et al. 2016). The lake expansion at $5800 \mathrm{cal}$ BP may have been caused by tectonic activity that dammed the outflow and rapidly enlarged the lake surface area. We were not able to exclude the possibility that additional neotectonic events shaped lake level changes since $5800 \mathrm{cal}$ BP. However, subsequent sediment accumulation showed no sharp breaks, accumulation of clay layers, or other indications of sudden lake level changes. After the lake expansion event, our geochemically based dataset supports a climatically induced long term increase in lake levels, peaking between 1050 and 400 cal BP. This fits well with the presence of algae (Botryococcus and Coelastrum) that indicates large expanses of shallow water between 2700 and 500 cal BP (Brugger 
Fig. 4 Palaeohydrological scenario developed for Lago Rogaguado, based on sedimentary evidence. Shoreline positions and the course of the Beni palaeoriverbed inside the modern lake in the scenarios are hypothetical to serve the purpose of illustrating the scenario. The lighter-yellow colored areas of this DEM represent relatively lower lying areas (148 m), whereas darker areas show progressively higher elevations ( $>170 \mathrm{~m})$. The points labeled 400 and 398 represent the two coring sites discussed in this study. (Color figure online)
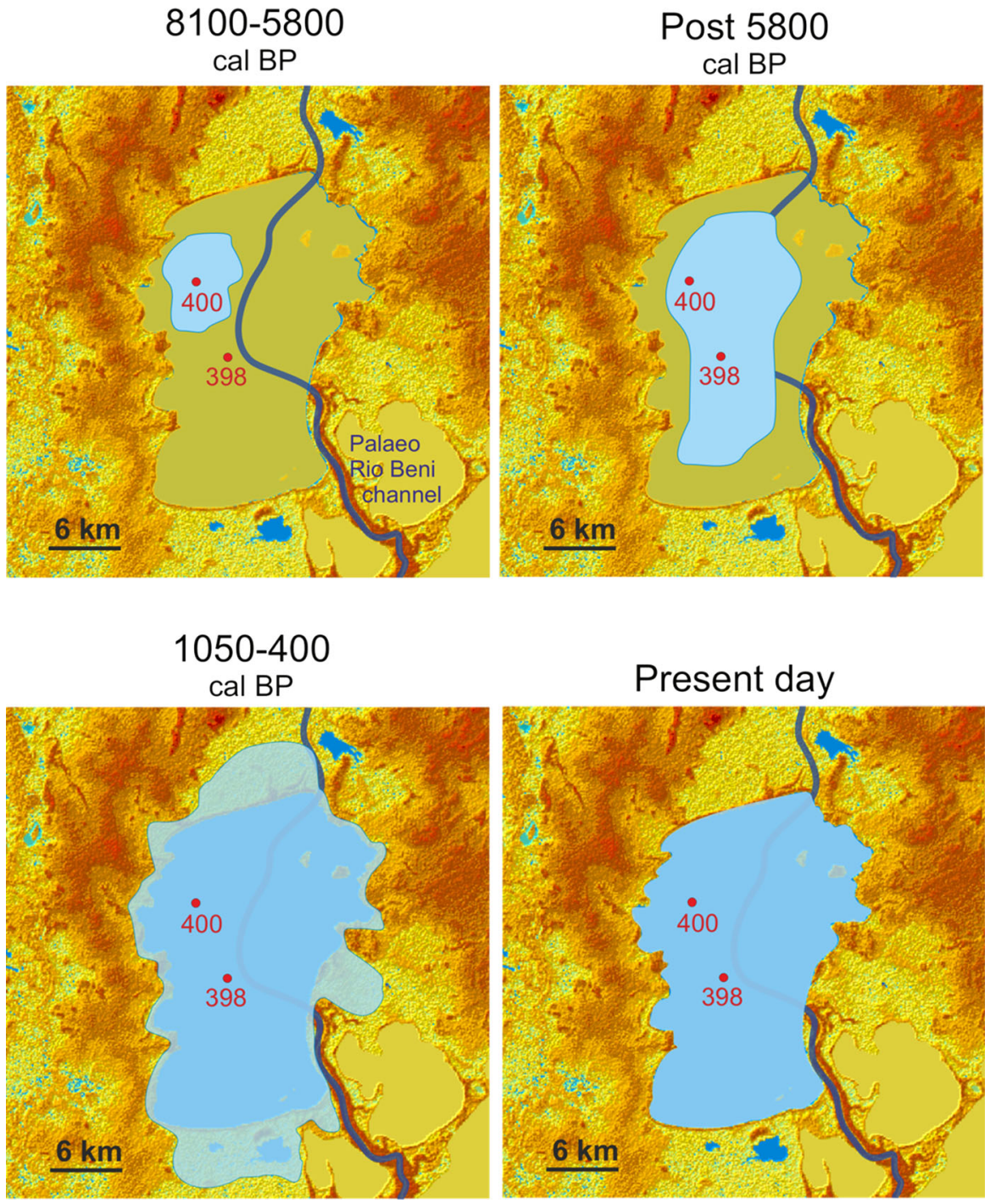

et al. 2016). Moreover, Brugger et al. (2016) found Tetraedron algae from 500-0 cal BP, possibly indicating lower $\mathrm{pH}$ driven by laterite erosion. The geochemical proxies ( $\mathrm{C}: \mathrm{N}, \mathrm{Zr}: \mathrm{Rb}$, and grain size) likewise support a scenario of increased watershed erosion from 400-0 cal BP. This may be a result of human influence such as erosion and land cover changes in the surrounding watershed, but also coincides with higher precipitation in the eastern Bolivian Andes (Apaéstegui et al., 2018).
Influence of human presence

The sedimentary record from Lago Rogaguado also provides information on possible effects of human activity in the region. Human presence in the immediate area dates to at least $10,800 \mathrm{cal} \mathrm{BP}$, with squash first cultivated around 10,250 cal BP, manioc around $10,350 \mathrm{cal} \mathrm{BP}$, and maize adopted around $6850 \mathrm{cal} \mathrm{BP}$ (Lombardo et al. 2020). Interestingly, this means that people were cultivating crops before the lake expansion event around 5800 cal BP. Surprisingly, the relatively low macroscopic charcoal accumulation rates (macroCHAR) prior to $1450 \mathrm{cal} \mathrm{BP}$ point to 
minimal fire-related disturbances in these early occupation phases.

Based on the lack of pollen from cultivated crops between 2800 and $500 \mathrm{cal} \mathrm{BP}$ and low microscopic charcoal accumulation rates (microCHAR; Fig. 2), Brugger et al. (2016) argued that little agricultural activity occurred during this time. However, the new contiguously-sampled macroCHAR record provides evidence that a distinct biomass-burning phase occurred around $1450 \mathrm{cal}$ BP. The elevated macroCHAR values coincided with the beginning of a fivefold increase in sedimentation rate around the same depth, suggesting that the sudden rise in macroCHAR could be influenced by the modeled sediment-accumulation rates (Finsinger et al. 2016). However, macroscopic charcoal concentrations also increase at this point, and we therefore exclude that the rapid macroCHAR increase was solely due to changing sediment accumulation rates. The marked increase in sedimentation rate after $1450 \mathrm{cal}$ BP supports the hypothesis of increased sediment erosion, which could be due to a land use change around the lake, as a decrease of vegetation cover in the buffer zone between agricultural land and the lakeshore is a primary reason for increased sedimentation rates in lakes (Gasiorowski 2008). The increase in sedimentation rate was coeval with an expansion of pioneer Cecropia species (Brugger et al. 2016), which is linked to disturbance and deforestation (Leyden 1987; Bush and Colinvaux 1994; Northrop and Horn 1996).

The marked increase in macroCHAR and sedimentation rate also coincides with the earliest radiocarbon ages from the monumental mound regions in the area of Trinidad (Lombardo et al. 2013b; Prümers and Betancourt 2014; de Souza et al. 2019), and the period when agricultural raised fields were first built in the central (Rodrigues et al. 2015) and northern (Walker 2004) Llanos de Moxos. Based on this evidence, it appears that 1500-1400 cal BP was a period of great expansion of pre-Columbian settlements in the Llanos de Moxos; both a time when new sites were occupied and old sites like the area around Lago Rogaguado may have been re-occupied.

LR-400 had a less pronounced local maximum in macroCHAR values between 400 and $100 \mathrm{cal} \mathrm{BP}$. This occurred during a period of substantial agricultural changes around Lago Rogaguado from $500 \mathrm{cal}$ BP to present, with peaks in Cerealia-type pollen, reappearance of maize pollen, and the first appearance of Avena-type pollen that indicate intense land use even after the arrival of Europeans (Brugger et al. 2016). Concurrent increases in $\mathrm{C}: \mathrm{N}$ and $\mathrm{Zr}: \mathrm{Rb}$, as well as a shift in the clay grain size fraction to silt (Fig. 2) point to greater erosion. However, we cannot exclude that higher precipitation during the LIA (Apaéstegui et al. 2018) may have contributed to increased sedimentation rate. Interestingly, a site located $250 \mathrm{~km}$ to the east of Lago Rogaguado showed a possible population decline around $600-500 \mathrm{cal} \mathrm{BP}$ (Carson et al. 2014), while another site only $30 \mathrm{~km}$ to the east of Lago Rogaguado showed a decline in burning and a protracted abandonment of raised field agriculture around 750-500 cal BP (Whitney et al. 2014). Our findings suggest that Lago Rogaguado's population continued to thrive until 400-100 cal BP a time marked by significant land use changes and the arrival of Europeans.

Today, less than a hundred villagers live around Lago Rogaguado. Slash and burn methods are used to clear land, however the present-day fire-activity signal based on macroCHAR reaches only $25 \%$ of the amplitude of the level reached at $1450 \mathrm{cal}$ BP. This probably relates to a decrease in population size as well as a change in subsistence strategies, which includes a major shift to cattle ranching in the Llanos de Moxos since the late eighteenth century (Denevan 1964).

\section{Conclusions}

The discovery of tropical soils underlying lacustrine material suggests that the site of present-day Lago Rogaguado was a heterogeneous environment that probably included swamps as well as seasonally dry savannahs prior to $8100 \mathrm{cal} \mathrm{BP}$. At $8100 \mathrm{cal} \mathrm{BP}$, site LR-400 began to accumulate sediment regularly, suggesting the presence of a precursor lake or continuously flooded backwater swamp. At $5800 \mathrm{cal}$ $\mathrm{BP}$, an abrupt shift in proxies at both coring sites LR400 and LR-398 points to a rapid lake level rise and expansion of Lago Rogaguado over the former floodplain of the Beni River. The lake expansion event at $5800 \mathrm{cal}$ BP occurred during a regionally dry climatic period, and tectonic activity likely dammed the valley and led to a sharp increase in the water level. Lake levels increased further until reaching a maximum level between 1050 and $400 \mathrm{cal} \mathrm{BP}$, as 
evidenced by the decreases in $\mathrm{C}: \mathrm{N}$ ratio, sedimentation rate, $\mathrm{Zr}: \mathrm{Rb}$, and grain size. Based on nearby climate records, this long-term increase in lake levels coincided with a wetter climate.

Concurrently, the effects of human activities around Lago Rogaguado can be tracked using charcoal, grain size, geochemistry, and sedimentation accumulation rates. Around $1450 \mathrm{cal} \mathrm{BP}$, an unprecedented maximum in macroscopic charcoal accumulation and a marked five-fold increase in sedimentation rate point to major anthropogenic fire activities around the lake. This timing coincides with the highest lake levels as well as the start of raised field agriculture. Extensive floods, which occur even today, may have been a very significant control on the settlement locations of populations in the Llanos de Moxos during this time. After $1450 \mathrm{cal} \mathrm{BP}$, macroscopic charcoal accumulation subsided gradually, with subdued increases between 400 and 100 cal BP that may be explained by a periodic maintenance of open areas. This was accompanied by higher $\mathrm{C}: \mathrm{N}, \mathrm{Zr}: \mathrm{Rb}$, and grain size, which support a scenario of increased watershed erosion over the same time period. Over the last century, fire activity decreased substantially, and agricultural activities using burning techniques faded to a minimal level. This probably marks the disappearance of the original indigenous population in the local area. Nowadays, cattle ranching dominates human impact in the area around Lago Rogaguado.

Lago Rogaguado's sediments, exemplified in cores LR-400 and LR-398, result from a combination of tectonic, fluvial, climate, and human landscape interactions in southern Amazonia throughout the mid-late Holocene. The previously published palynological record from the lake (Brugger et al. 2016) combined with the geochemical proxies analyzed in this study provide a record of environmental and human impacts that expand our understanding of how the Llanos de Moxos has changed over the past 8000 years.

Acknowledgements We are grateful to S. Brugger for laboratory and fieldwork assistance throughout the project, W. Tinner and members of the Palaeoecology Group at the Institute of Plant Sciences (University of Bern) for discussions and the funding of several AMS dates, L. Rodrigues for fieldwork assistance, D. Fischer for laboratory analyses, H. Vogel and F. Anselmetti for XRF analyses, D. Hodell for providing feedback on the manuscript, and the editors and reviewers for further helpful comments and suggestions. We are indebted to the residents of Coquinal around Lago Rogaguado for their hospitality and fieldwork assistance.
Open Access This article is licensed under a Creative Commons Attribution 4.0 International License, which permits use, sharing, adaptation, distribution and reproduction in any medium or format, as long as you give appropriate credit to the original author(s) and the source, provide a link to the Creative Commons licence, and indicate if changes were made. The images or other third party material in this article are included in the article's Creative Commons licence, unless indicated otherwise in a credit line to the material. If material is not included in the article's Creative Commons licence and your intended use is not permitted by statutory regulation or exceeds the permitted use, you will need to obtain permission directly from the copyright holder. To view a copy of this licence, visit http://creativecommons.org/licenses/by/4.0/.

Funding This work was supported by a grant from the Swiss National Science Foundation (SNF) [200020-141277/1] and AHRC-FAPESP MoU research grant HERCA, reference AH/ S001662/1.

\section{References}

Apaéstegui J, Cruz FW, Vuille M, Fohlmeister J, Espinoza JC, Sifeddine A, Strikis N, Guyot JL, Ventura R, Cheng H, Edwards RL (2018) Precipitation changes over the eastern Bolivian Andes inferred from speleothem $\left(\delta^{18} \mathrm{O}\right)$ records for the last 1400 years. Earth Planet Sci Lett 494:124-134. https://doi.org/10.1016/j.epsl.2018.04.048

Arroyo-Kalin M, Neves E, Woods W (2009) Anthropogenic dark earths of the central amazon region: remarks on their evolution and phylogenetic composition. In: Woods WI, Teixeira WG, Lehmann J, Steiner C, WinklerPrins A, Rebellato L (eds) Amazonian Dark Earths: Wim Sombroek's Vision. Springer, Netherlands, pp 99-125. https:// doi.org/10.1007/978-1-4020-9031-8_5

Baker PA, Seltzer GO, Fritz SC, Dunbar RB, Grove MJ, Tapia PM, Cross SL, Rowe HD, Broda JP (2001) The history of South American tropical precipitation for the past 25,000 years. Science 291(5504):640-643. https://doi.org/10. 1126/science. 291.5504 .640

Birks HJB, Heegaard E (2003) Developments in age-depth modelling of Holocene stratigraphical sequences. PAGES News 11:7-8. https://doi.org/10.22498/pages.11.2-3.7

Björck S, Wohlfarth B $(2001){ }^{14} \mathrm{C}$ chronostratigraphic techniques in paleolimnology. In: Last WM, Smol JP (eds) Tracking Environmental Change Using Lake Sediments, vol 1. Springer, Dordrecht, pp 205-245. https://doi.org/10. 1007/0-306-47669-X_10

Blaauw M (2010) Methods and code for 'classical' age-modelling of radiocarbon sequences. Quat Geochronol 5(5):512-518. https://doi.org/10.1016/j.quageo.2010.01. 002

Brown ET (2011) Lake Malawi's response to "megadrought" terminations: Sedimentary records of flooding, weathering and erosion. Palaeogeogr Palaeoclimatol Palaeoecol 303:120 125. https://doi.org/10.1016/j.palaeo.2010.01.038 
Brugger SO, Gobet E, van Leeuwen JFN, Ledru M, Colombaroli D, van der Knaap WO, Lombardo U, Escobar-Torrez K, Finsinger W, Rodrigues L, Giesche A, Zarate M, Veit H, Tinner W (2016) Long-term man-environment interactions in the Bolivian Amazon: 8000 years of vegetation dynamics. Quat Sci Rev 132:114-128. https://doi.org/10. 1016/j.quascirev.2015.11.001

Burnett AP, Soreghan MJ, Scholz CA, Brown ET (2011) Tropical East African climate change and its relation to global climate: A record from Lake Tanganyika, Tropical East Africa, over the past 90+ kyr. Palaeogeogr Palaeoclimatol Palaeoecol 303:155-167. https://doi.org/10.1016/ j.palaeo.2010.02.011

Bush MB, Colinvaux PA (1994) Tropical forest disturbance: paleoecological records from Darien Panama. Ecology 75(6):1761-1768. https://doi.org/10.2307/1939635

Bush MB, Silman MR (2007) Amazonian exploitation revisited: ecological asymmetry and the policy pendulum. Front Ecol Environ 5:457-465. https://doi.org/10.1890/070018

Bush MB, Gosling WD, Colinvaux PA (2011) Climate and vegetation change in the lowlands of the Amazon Basin. In: Bush M, Flenley J, Gosling W (eds) Tropical Rainforest Responses to Climatic Change. Springer, Berlin, pp 61-84. https://doi.org/10.1007/978-3-642-05383-2_3

Bush MB, Correa-Metrio A, McMichael CH, Sully S, Shadik CR, Valencia BG, Guilderson T, Steinitz-Kanna M, Overpeck JT (2016) A 6900-year history of landscape modification by humans in lowland Amazonia. Quat Sci Rev 141:52-64. https://doi.org/10.1016/j.quascirev.2016. 03.022

Capriles JM, Lombardo U, Maley B, Zuna C, Veit H, Kennett DJ (2019) Persistent Early to Middle Holocene tropical foraging in southwestern Amazonia. Sci Adv 5(4):5449. https://doi.org/10.1126/sciadv.aav5449

Carson JF, Whitney BS, Mayle FE, Iriarte J, Prümers H, Soto JD, Watling J (2014) Environmental impact of geometric earthwork construction in pre-Columbian Amazonia. P Natl Acad Sci USA 111(29):10497-10502. https://doi. org/10.1073/pnas.1321770111

Carson JF, Watling J, Mayle FE, Whitney BS, Iriarte J, Prümers $\mathrm{H}$, Soto JD (2015) Pre-Columbian land use in the ring-ditch region of the Bolivian Amazon. Holocene 25(8):12851300. https://doi.org/10.1177/0959683615581204

Carter SJ, Colman SM (1994) Biogenic silica in Lake Baikal sediments: results from 1990-1992 American cores. J Great Lakes Res 20(4):751-760. https://doi.org/10.1016/ S0380-1330(94)71192-8

Chawchai S, Chabangborn A, Kylander M, Löwemark L, Mörth CM, Blaauw M, Klubseang W, Reimer PJ, Fritz SC, Wohlfarth B (2013) Lake Kumphawapi-an archive of Holocene Palaeoenvironmental and palaeoclimatic changes in northeast Thailand. Quat Sci Rev 68:59-75. https:// doi.org/10.1016/j.quascirev.2013.01.030

Cheng H, Sinha A, Cruz FW, Wang X, Edwards RL, d'Horta FM, Ribas CC, Vuille M, Stott LD, Auler AS (2013) Climate change patterns in Amazonia and biodiversity. Nat Commun 4:1411. https://doi.org/10.1038/ncomms2415

Clement CR, Junqueira AB (2010) Between a Pristine Myth and an Impoverished Future. Biotropica 42(5):534-536. https://doi.org/10.1111/j.1744-7429.2010.00674.x
Clement CR, Denevan WM, Heckenberger MJ, Junqueira AB, Neves EG, Teixeira WG, Woods WI (2015) The domestication of Amazonia before European conquest. P Roy Soc B-Biol Sci 282(1812):20150813. https://doi.org/10.1098/ rspb.2015.0813

Cleveland WS (1979) Robust locally weighted regression and smoothing scatterplots. J Am Stat Assoc 74(368):829-836. https://doi.org/10.1080/01621459.1979.10481038

Croudace IW, Rindby A, Rothwell RG (2006) ITRAX: description and evaluation of a new multi-function X-ray core scanner. Geol Soc Spec Publ 267:51. https://doi.org/ 10.1144/GSL.SP.2006.267.01.04

Cushing EJ, Wright HE Jr (1965) Hand-operated piston corers for lake sediments. Ecology 46(3):380-384. https://doi. org/10.2307/1936353

Cruz FW, Vuille M, Burns SJ, Wang X, Cheng H, Werner M, Edwards RL, Karmann I, Auler AS, Nguyen H (2009) Orbitally driven east-west antiphasing of South American precipitation. Nat Geosci 2(3):210-214. https://doi.org/10. 1038/ngeo444

Davies SJ, Lamb HF, Roberts SJ (2015) Micro-XRF core scanning in palaeolimnology: recent developments. In: Croudace IW, Rothwell RG (eds) Micro-XRF Studies of Sediment Cores. Springer, Dordrecht, pp 189-226. https:// doi.org/10.1007/978-94-017-9849-5_7

Dean WE Jr (1974) Determination of carbonate and organic matter in calcareous sediments and sedimentary rocks by loss on ignition: comparison with other methods. J Sediment Res 44(1):242-248. https://doi.org/10.1306/ 74D729D2-2B21-11D7-8648000102C1865D

Denevan WM (1964) Pre-Spanish earthworks in the Llanos de Mojos of northeastern Bolivia. Rev Geogr Acad 33(60):17-25. www.jstor.org/stable/40991767

Denevan WM (1966) A Cultural-Ecological View of the Former Aboriginal Settlement in the Amazon Basin. Prof Geogr 18(6):346-351. https://doi.org/10.1111/j.0033-0124.1966. 00346.x

Denevan WM (1992) The pristine myth: the landscape of the Americas in 1492. Ann Am Assoc Geogr 82(3):369-385. https://doi.org/10.1111/j.1467-8306.1992.tb01965.x

Denevan WM (2012) Rewriting the late Pre-European history of Amazonia. J Lat Am Geogr 11(1):9-24. https://doi.org/10. 1353/lag.2012.0001

de Souza JG, Robinson M, Maezumi SY, Capriles J, Hoggarth JA, Lombardo U, Novello VF, Apaéstegui J, Whitney B, Urrego D, Alves DT (2019) Climate change and cultural resilience in late pre-Columbian Amazonia. Nat Ecol Evol 3:1007-1017. https://doi.org/10.1038/s41559-019-0924-0

Dumont JF, Fournier M (1994) Geodynamic environment of Quaternary morphostructures of the subandean foreland basins of Peru and Bolivia: characteristics and study methods. Quat Int 21:129-142. https://doi.org/10.1016/ 1040-6182(94)90027-2

Dumont JF (1996) Neotectonics of the subandes-Brazilian craton boundary using geomorphological data: the Maranon and Beni basins. Tectonophysics 259(1):137-151. https:// doi.org/10.1016/0040-1951(95)00200-6

Erickson CL (2000) An artificial landscape-scale fishery in the Bolivian Amazon. Nature 408(6809):190. https://doi.org/ 10.1038/35041555 
Erickson CL (2008) Amazonia: the historical ecology of a domesticated landscape. In: Silverman H, Isbell WH (eds) Handbook of South American Archaeology. Springer, Berlin, pp 157-183. https://doi.org/10.1007/978-0-38774907-5_11

Espurt N, Baby P, Brusset S, Roddaz M, Hermoza W, Regard V, Antoine PO, Salas-Gismondi R, Bolanos R (2007) How does the Nazca Ridge subduction influence the modern Amazonian foreland basin? Geology 35(6):515-518. https://doi.org/10.1130/G23237A.1

Finsinger W, Kelly R, Fevre J, Magyari EK (2014) A guide to screening charcoal peaks in macrocharcoal-area records for fire-episode reconstructions. Holocene 24(8):10021008. https://doi.org/10.1177/0959683614534737

Finsinger W, Fevre J, Orbán I, Pál I, Vincze I, Hubay K, Birks HH, Braun M, Tóth M, Magyari EK (2016) Holocene fireregime changes near the treeline in the Retezat Mts (Southern Carpathians, Romania). Quat Int 477:94-105. https://doi.org/10.1016/j.quaint.2016.04.029

Fornace KL, Whitney BS, Galy V, Hughen KA, Mayle FE (2016) Late Quaternary environmental change in the interior South American tropics: new insight from leaf wax stable isotopes. Earth Planet Sci Lett 438:75-85. https:// doi.org/10.1016/j.eps1.2016.01.007

Garreaud R, Vuille M, Clement AC (2003) The climate of the Altiplano: observed current conditions and mechanisms of past changes. Palaeogeogr Palaeoclimatol Palaeoecol 194(1): 5-22. https://doi.org/10.1016/S0031-0182(03)00269-4

Gasiorowski M (2008) Deposition rate of lake sediments under different alternative stable states. Geochronometria 32(1):29-35. https://doi.org/10.2478/v10003-008-0020-y

Guyot JL (1992). Hydrogéochimie des fleuves de l'Amazonie bolivienne. Doctoral dissertation, Bordeaux.

Haberzettl T, Fey M, Lücke A, Maidana N, Mayr C, Ohlendorf C, Schäbitz F, Schleser GH, Wille M, Zolitschka B (2005) Climatically induced lake level changes during the last two millennia as reflected in sediments of Laguna Potrok Aike, southern Patagonia (Santa Cruz, Argentina). J Paleolimnol 33(3):283-302. https://doi.org/10.1007/s10933-004-5331-z

Håkanson L, Jansson M (2002) Principles of Lake Sedimentology. Springer, Berlin Heidelberg. https://doi.org/10. 1002/iroh.19850700318

Hampel A (2002) The migration history of the Nazca Ridge along the Peruvian active margin: a re-evaluation. Earth Planet Sci Lett 203(2):665-679. https://doi.org/10.1016/ S0012-821X(02)00859-2

Hanagarth W (1993) Acerca de la geoecología de las sabanas del Beni en el noreste de Bolivia. Instituto de Ecología, La Paz

Heegaard E, Birks HJB, Telford RJ (2005) Relationships between calibrated ages and depth in stratigraphical sequences: an estimation procedure by mixed-effect regression. Holocene 15(4):612-618. https://doi.org/10. 1191/0959683605hl836rr

Heiri O, Lotter AF, Lemcke G (2001) Loss on ignition as a method for estimating organic and carbonate content in sediments: reproducibility and comparability of results. J Paleolimnol 25(1):101-110. https://doi.org/10.1023/A: 1008119611481

Higuera PE, Brubaker LB, Anderson PM, Hu FS, Brown TA (2009) Vegetation mediated the impacts of postglacial climate change on fire regimes in the south-central Brooks
Range Alaska. Ecol Monogr 79(2):201-219. https://doi. org/10.1890/07-2019.1

Hogg AG, Hua Q, Blackwell PG, Niu M, Buck CE, Guilderson TP, Heaton TJ, Palmer JG, Reimer PJ, Reimer RW, Turney CS, Zimmerman SR (2013) SHCal13 Southern Hemisphere calibration, 0-50,000 cal yr BP. Radiocarbon 55(4):1889-1903. https://doi.org/10.2458/azu_js_rc.55. 16783

Kanner LC, Burns SJ, Cheng H, Edwards RL, Vuille M (2013) High-resolution variability of the South American summer monsoon over the last seven millennia: insights from a speleothem record from the central Peruvian Andes. Quat Sci Rev 75:1-10. https://doi.org/10.1016/j.quascirev.2013. 05.008

Koch A, Brierley C, Maslin MM, Lewis SL (2019) Earth system impacts of the European arrival and Great Dying in the Americas after 1492. Quat Sci Rev 207:13-36. https://doi. org/10.1016/j.quascirev.2018.12.004

Kylander ME, Ampel L, Wohlfarth B, Veres D (2011) Highresolution X-ray fluorescence core scanning analysis of Les Echets (France) sedimentary sequence: new insights from chemical proxies. J Quat Sci 26(1):109-117. https://doi. org/10.1002/jqs. 1438

Last WM (2002) Textural analysis of lake sediments. In: Last WM, Smol JP (eds) Tracking Environmental Change Using Lake Sediments, vol 2. Springer, Netherlands, pp 41-81. https://doi.org/10.1007/0-306-47670-3_4

Leyden BW (1987) Man and climate in the Maya lowlands. Quat Res 28(3):407-414. https://doi.org/10.1016/00335894(87)90007-X

Levis C, Costa FR, Bongers F, Peña-Claros M, Clement CR, Junqueira $A B$ et al (2017) Persistent effects of preColumbian plant domestication on Amazonian forest composition. Science 355(6328):925-931. https://doi.org/ 10.1126/science.aal0157

Livingstone DA (1955) A lightweight piston sampler for lake deposits. Ecology 36(1):137-139. https://doi.org/10.2307/ 1931439

Lombardo U, Prümers H (2010) Pre-Columbian human occupation patterns in the eastern plains of the Llanos de Moxos, Bolivian Amazonia. J Archaeol Sci 37(8):1875-1885. https://doi.org/ 10.1016/j.jas.2010.02.011

Lombardo U, Canal-Beeby E, Fehr S, Veit H (2011) Raised fields in the Bolivian Amazonia: a prehistoric green revolution or a flood risk mitigation strategy? J Archaeol Sci 38(3):502-512. https://doi.org/10.1016/j.jas.2010.09.022

Lombardo U, Szabo K, Capriles JM, May JH, Amelung W, Hutterer R, Lehndorff E, Plotzki A, Veit H (2013) Early and middle holocene hunter-gatherer occupations in Western Amazonia: the hidden shell middens. PLoS ONE 8(8):e72746. https://doi. org/10.1371/journal.pone.0072746

Lombardo U, Denier S, May JH, Rodrigues L, Veit H (2013) Human-environment interactions in pre-Columbian Amazonia: The case of the Llanos de Moxos, Bolivia. Quat Int 312:109-119. https://doi.org/10.1016/j.quaint.2013.01. 007

Lombardo U, Veit H (2014) The origin of oriented lakes: Evidence from the Bolivian Amazon. Geomorphology 204:502-509. https://doi.org/10.1016/j.geomorph.2013. 08.029 
Lombardo U (2014) Neotectonics, flooding patterns and landscape evolution in southern Amazonia. Earth Surf Dyn 2(2):635-679. https://doi.org/10.5194/esurf-2-493-2014

Lombardo U (2016) Alluvial plain dynamics in the southern Amazonian foreland basin. Earth Sys Dyn 7(2):453-467. https://doi.org/10.5194/esd-7-453-2016

Lombardo U, Rodrigues L, Veit H (2018) Alluvial plain dynamics and human occupation in SW Amazonia during the Holocene: A paleosol-based reconstruction. Quat Sci Rev 180:30-41. https://doi.org/10.1016/j.quascirev.2017. 11.026

Lombardo U, Iriarte J, Hilbert L, Ruiz-Pérez J, Capriles JM, Veit H (2020) Early Holocene crop cultivation and landscape modification in Amazonia. Nature 581:190-193. https:// doi.org/10.1038/s41586-020-2162-7

Mayle FE, Burbridge R, Killeen TJ (2000) Millennial-scale dynamics of southern Amazonian rain forests. Science 290(5500):2291-2294. https://doi.org/10.1126/science. 290.5500 .2291

Mayle FE, Beerling DJ, Gosling WD, Bush MB (2004) Responses of Amazonian ecosystems to climatic and atmospheric carbon dioxide changes since the last glacial maximum. P Roy Soc B-Biol Sci 359(1443):499-514. https://doi.org/10.1098/rstb.2003.1434

Mayle FE, Langstroth RP, Fisher RA, Meir P (2007) Long-term forest-savannah dynamics in the Bolivian Amazon: implications for conservation. P Roy Soc B-Biol Sci 362(1478):291-307. https://doi.org/10.1098/rstb.2006. 1987

Mayle FE, Power MJ (2008) Impact of a drier Early-MidHolocene climate upon Amazonian forests. P Roy Soc B-Biol Sci 363(1498):1829-1838. https://doi.org/10.1098/ rstb.2007.0019

McMichael CH, Piperno DR, Bush MB, Silman MR, Zimmerman AR, Raczka MF, Lobato LC (2012) Sparse preColumbian human habitation in western Amazonia. Science 336(6087):1429-1431. https://doi.org/10.1126/scie nce. 1219982

Melack JM, Hess LL (2011) Remote sensing of the distribution and extent of wetlands in the Amazon basin. In: Junk WJ, Piedade MTF, Wittmann F, Schöngart J, Parolin P (eds) Amazonian Floodplain Forests. Springer, Netherlands, pp 43-59. https://doi.org/10.1007/978-90-481-8725-6_3

Messerli B, Grosjean M, Hofer T, Nunez L, Pfister C (2000) From nature-dominated to human-dominated environmental changes. Quat Sci Rev 19(1-5):459-479. https:// doi.org/10.1016/S0277-3791(99)00075-X

Metcalfe SE, Whitney BS, Fitzpatrick KA, Mayle FE, Loader NJ, Street-Perrott FA, Mann DG (2014) Hydrology and climatology at Laguna La Gaiba, lowland Bolivia: complex responses to climatic forcings over the last 25000 years. J Quat Sci 29(3):289-300. https://doi.org/10.1002/ jqs. 2702

Meyer-Christoffer A, Becker A, Finger P, Schneider U, and Ziese M (2018) GPCC Climatology Version 2018 at $0.25^{\circ}$ : Monthly Land-Surface Precipitation Climatology for Every Month and the Total Year from Rain-Gauges built on GTS-based and Historical Data. https://doi.org/10.5676/ DWD_GPCC/CLIM_M_V2018_025

Meyers PA, Teranes JL (2001) Sediment organic matter. In: Last WM, Smol JP (eds) Tracking Environmental Change
Using Lake Sediments, vol 2. Springer, Netherlands, pp 239-269. https://doi.org/10.1007/0-306-47670-3_9

Navarro-Sánchez G (2011) Clasificación de la Vegetación de Bolivia. Centro de Ecología y Difusión Simón I. Patiño, Santa Cruz, Bolivia

Neves EG (2008) Ecology, Ceramic Chronology and Distribution, Long-term History, and Political Change in the Amazonian Floodplain. In: Silverman H, Isbell WH (eds) Handbook of South American archaeology. Springer, Berlin, pp 359-379. https://doi.org/10.1007/978-0-38774907-5_20

Northrop LA, Horn SP (1996) PreColumbian agriculture and forest disturbance in Costa Rica: palaeoecological evidence from two lowland rainforest lakes. Holocene 6(3):289-299. https:// doi.org/10.1177/095968369600600304

Novello VF, Cruz FW, Vuille M, Stríkis NM, Edwards RL, Cheng H, Emerick S, de Paula MS, Li X, Barreto EDS, Karmann I, Santos RV (2017) A high-resolution history of the South American Monsoon from Last Glacial Maximum to the Holocene. Sci Rep 7:44267. https://doi.org/10.1038/ srep44267

Pärssinen M, Schaan D, Ranzi A (2009) Pre-Columbian geometric earthworks in the upper Purús: a complex society in western Amazonia. Antiquity 83(322):1084-1095. https:// doiorg.ezp.lib.cam.ac.uk/10.1017/S0003598X00099373

Plafker G (1964) Oriented lakes and lineaments of northeastern Bolivia. Geol Soc Am Bull 75(6):503-522. https://doi.org/ 10.1130/0016-7606(1964)75[503:OLALON]2.0.CO;2

Plotzki A, May JH, Veit H (2011) Review of past and recent fluvial dynamics in the Beni lowlands. NE Bolivia. Geogr Helv 66(3):164-172. https://doi.org/10.5194/gh-66-1642011

Prümers H, Jaimes Betancourt C (2014) 100 años de investigación arqueológica en los Llanos de Mojos. Arqueoantropológicas año 4(4):11-54

Rodrigues L, Lombardo U, Fehr S, Preusser F, Veit H (2015) Pre-Columbian agriculture in the Bolivian Lowlands: Construction history and management of raised fields in Bermeo. CATENA 132:126-138. https://doi.org/10.1016/ j.catena.2014.08.021

Rodrigues L, Lombardo U, Beeby EC, Veit H (2016) Linking soil properties and pre-Columbian agricultural strategies in the Bolivian lowlands: the case of raised fields in Exaltación. Quat Int 437:143-155. https://doi.org/10.1016/j. quaint.2015.11.091

Rodrigues L (2016) Pre-Columbian raised fields agriculture in the Llanos de Moxos, Bolivian Amazon. Institute of Geography, University of Bern, pp. 1-201

Schaan DP (2008) The nonagricultural chiefdoms of Marajó Island. In: Silverman H, Isbell WH (eds) The handbook of South American archaeology. Springer New York, pp 339-357. https://doiorg.ezp.lib.cam.ac.uk/10.1007/ 978-0-387-74907-5_19

Stallard RF, Edmond JM (1983) Geochemistry of the Amazon 2. The influence of geology and weathering environment on the dissolved load. J Geophys Res 88(14):9671-9688. https://doi.org/10.1029/JC088iC14p09671

Stuiver M, Reimer P (1993) Extended 14C data base and revised CALIB 3.014 C age calibration program. Radiocarbon 35:215-230. https://doi.org/10.1017/S0033822200013904 
Sun D, Bloemendal J, Rea DK, Vandenberghe J, Jiang F, An Z, Su R (2002) Grain-size distribution function of polymodal sediments in hydraulic and aeolian environments, and numerical partitioning of the sedimentary components. Sediment Geol 152(3):263-277. https://doi.org/10.1016/ S0037-0738(02)00082-9

Taylor ZP, Horn SP, Mora CI, Orvis KH, Cooper LW (2010) A multi-proxy palaeoecological record of late-Holocene forest expansion in lowland Bolivia. Palaeogeogr Palaeoclimatol Palaeoecol 293(1):98-107. https://doi.org/10. 1016/j.palaeo.2010.05.004

Talbot MR, Lærdal T (2000) The Late Pleistocene-Holocene palaeolimnology of Lake Victoria, East Africa, based upon elemental and isotopic analyses of sedimentary organic matter. J Paleolimnol 23(2):141-164. https://doi.org/10. 1023/A:1008029400463

Tapia PM, Fritz SC, Baker PA, Seltzer GA, Dunbar RB (2003) A Late Quaternary diatom record of tropical climatic history from Lake Titicaca (Peru and Bolivia). Palaeogeogr Palaeoclimatol Palaeoecol 194(1-3):139-164. https://doi. org/10.1016/S0031-0182(03)00275-X

Tinner W, Conedera M, Ammann B, Gaggeler HW, Gedye S, Jones R, Sagesser B (1998) Pollen and charcoal in lake sediments compared with historically documented forest fires in southern Switzerland since AD 1920. Holocene 8(1):31-42. https://doi.org/10.1191/095968398667205430

Tyuleneva V (2010) Cuatro viajes a la amazonía Boliviana. Foro Boliviano sobre Medio Ambiente y Desarrollo, La Paz, Bolivia

Urrego DH, Bush MB, Silman MR, Correa-Metrio AY, Ledru MP, Mayle FE, Paduano G, Valencia BG (2009) Millennial-scale ecological changes in tropical South America since the last glacial maximum. In: Vimeux F, Sylvestre F, Khodri M (eds) Past Climate Variability in South America and Surrounding Regions. Springer, Netherlands, pp 283-300. https://doi.org/10.1007/978-90-481-2672-9_ 12

Urrego DH, Bush MB, Silman MR, Niccum BA, La Rosa P, McMichael CH, Hagen S, Palace M (2013) Holocene fires, forest stability and human occupation in south-western Amazonia. J Biogeogr 40(3):521-533. https://doi.org/10. 1111/jbi.12016

Walker JH (2004) Agricultural change in the Bolivian Amazon (No. 13). University of Pittsburgh, Pittsburgh, USA.

Walker JH (2011) Amazonian Dark Earth and Ring Ditches in the Central Llanos de Mojos, Bolivia. Cult Agric Food
Environ 33(1):2-14. https://doi.org/10.1111/j.2153-9561. 2011.01043.x

Weide DM, Fritz SC, Hastorf CA, Bruno MC, Baker PA, Guedron S, Salenbien W (2017) A 6000 yr diatom record of mid- to late Holocene fluctuations in the level of Lago Wiñaymarca, Lake Titicaca (Peru/Bolivia). Quat Res 88(2):179-192. https://doi.org/10.1017/qua.2017.49

Whitlock C, Larsen C (2001) Charcoal as a fire proxy. In: Smol JP, Birks JB, Last WM, Raymond SB, Alverson K (eds) Tracking environmental change using lake sediments, vol 3. Springer, Netherlands, pp 75-97. https://doi.org/10. 1007/0-306-47668-1_5

Whitney BS, Mayle FE, Punyansena SW, Fitzpatrick KA, Burn MJ, Guillen R, Chavez E, Mann D, Pennington T, Metcalfe SE (2011) A 45kyr palaeoclimate record from the lowland interior of tropical South America. Palaeogeogr Palaeoclimatol Palaeoecol 301(1-4):177-192. https://doi.org/10. 1016/j.palaeo.2011.05.012

Whitney BS, Dickau R, Mayle FE, Soto JD, Iriarte J (2013) PreColumbian landscape impact and agriculture in the Monumental Mound region of the Llanos de Moxos, lowland Bolivia. Quat Res 80(2):207-217. https://doi.org/10.1016/ j.yqres.2013.06.005

Whitney BS, Dickau R, Mayle FE, Walker JH, Soto JD, Iriarte J (2014) Pre-Columbian raised-field agriculture and land use in the Bolivian Amazon. Holocene 24(2):231-241. https:// doi.org/10.1177/0959683613517401

Young A (1980) Tropical soils and soil survey. Cambridge University Press, Cambridge UK. https://doi.org/10.1017/ S0014479700011753

Zhan S, Beck R, Hinkel K, Liu H, Jones B (2014) Spatio-temporal analysis of gyres in oriented lakes on the Arctic Coastal Plain of northern Alaska based on remotely sensed images. Remote Sens 6(10):9170-9193. https://doi.org/10. 3390/rs6109170

Zhou J, Lau KM (1998) Does a monsoon climate exist over South America? J Clim 11(5):1020-1040. https://doi.org/ 10.1175/1520-0442(1998)011\%3c1020:DAMCEO\%3e2. $0 . \mathrm{CO} ; 2$

Publisher's Note Springer Nature remains neutral with regard to jurisdictional claims in published maps and institutional affiliations. 